\title{
Methods of aril removal and lightness conditions on seeds physiological quality of sour passion fruits
}

\author{
R. C. Colombo ${ }^{a *}$, D. S. Costa ${ }^{a}$, D. U. Carvalho ${ }^{a}$, M. A. Cruz C $^{a}$ and S. R. Roberto ${ }^{a}$ \\ aPrograma de Pós-graduação em Agronomia, Departamento de Agronomia, Universidade Estadual de Londrina - UEL, \\ Rodovia Celso Garcia Cid, PR 445, Km 380, CP 6001, CEP 86051-990, Londrina, PR, Brasil \\ *e-mail: ronancolombo@yahoo.com.br
}

Received: April 17, 2017 - Accepted: January 9, 2018 - Distributed: August 31, 2019

\begin{abstract}
Passion fruits species presents a larger economic importance for in natura consumption and industry. The main way to propagate these species is by seeds; however, the aril presence and environmental conditions may inhibit the seeds germination. In this sense, the objective of this study was to evaluate the effect of aril removal methods and light conditions on $P$. edulis var. flavicarpa seeds quality and germination. There were used five methods to remove the seeds aril: (1) friction on steel mesh sieve for 5 minutes; (2) friction with coarse sand on steel mesh sieve for 5 minutes; (3) immersion in lime solution at $10 \%(\mathrm{w} / \mathrm{v})$, for 30 minutes; (4) fermentation in sugar solution at $10 \%(\mathrm{w} / \mathrm{v})$, during 48 hours; and (5) natural pulp fermentation, during five days. The seeds were submitted to germination test at darkness and lightness, as well as, to length seedlings and emergence test. Regardless the aril removal method, the germination percentage was lower at lightness than darkness highlighting the natural pulp fermentation treatment, which presented $86 \%$ of seeds germinated. On the other hand, the aril removal methods did not affect the seedlings emergence, with emergence percentages ranged from 88 to $94 \%$.
\end{abstract}

Keywords: Passiflora edulis, seed germination, seedlings length, darkness, dormancy.

\section{Métodos de remoção do arilo e condições de luminosidade sobre a qualidade fisiológica das sementes de maracujá azedo}

\section{Resumo}

As espécies de maracujá apresentam grande importância econômica, tanto para o consumo in natura, quanto para a indústria. A principal maneira de propagar essas espécies é por sementes; contudo, a presença de arilo e condições ambientais pode inibir a germinação. Nesse sentido, objetivou-se estudar o efeito de métodos de remoção do arilo e luminosidade na qualidade e germinação das sementes de Passiflora edulis var. flavicarpa. Cinco métodos foram empregados para a remoção do arilo: (1) fricção em peneira de malha de aço por cinco minutos; (2) fricção com areia grossa em peneira de malha de aço por cinco minutos; (3) imersão em solução de cal a $10 \%$ (m/v), por 30 minutos; (4) fermentação da polpa em solução de açúcar a $10 \%(\mathrm{~m} / \mathrm{v})$, por 48 horas; e (5) fermentação natural da polpa, por cinco dias. As sementes foram submetidas ao teste de germinação no escuro e no claro, teste de comprimento de plântulas e teste de emergência. Independente do método de remoção do arilo, a porcentagem de germinação no claro apresentou-se menor em comparação ao escuro, com destaque para o tratamento de fermentação natural da polpa, o qual apresentou $86 \%$ de sementes germinadas. Por outro lado, os métodos de remoção do arilo não afetaram a emergência das plântulas, com porcentagem de emergência variando entre 88 a $94 \%$.

Palavras-chave: Passiflora edulis, germinação de sementes, comprimento de plântulas, escuro, dormência.

\section{Introduction}

The Passifloraceae family is represented in South America by four genera, which the Passiflora is constituted by over 500 species, approximately 150 originated from Brazil (Campos et al., 2007; Hansen et al., 2006) where the largest center of geographic distribution of this genus occurs in the northern central region (Faleiro et al., 2005). Among these species, the yellow passion fruit (Passiflora edulis Sims) is considered the most important specie in Brazil, representing 95\% of commercial yields in passion fruit (Campos et al., 2007).

Passiflora species can be propagated by seeds or asexually by grafting, cuttings or in vitro propagation; however, the seeds propagation is the most used method (Araújo et al., 2007; Pantano, 2007; Zucareli et al., 2015). According to Delanoy et al. (2006) the Passiflora seeds germination may occurs from ten days to three months, 
showing a low germination percentage and irregularity in seedlings development. However, Tozzi and Takaki (2011) reported that the primary root protrusion occurred just from sixth day after sowing for $P$. edulis.

The irregularity of seeds germination can be caused by dormancy mechanisms, which control the water absorption by seeds, considered as physical or physiological dormancy (Alexandre et al., 2004; Marcos-Filho, 2015; Dalling et al., 2011). The P. edulis var. flavicarpa is a specie that presents seeds involved by aril and hard seed coat with a semi-permeable inner layer (Delanoy et al., 2006), which confers a combination of physical and physiological dormancy (Alexandre et al., 2004).

The physical dormancy plays a key role protecting seeds against microbial and predator attacks, as well as, the seed banks maintenance in the soil. In the other hand, compounds that inhibit seed imbibition or regulate the hormones balance during the germination process, as abscisic acid and gibberellic acid, cause physiological dormancy (Bewley et al., 2013).

For seedling growers, the irregularity of seed germination, caused by dormancy is not desired; then, it is important to study methods to overcome seed dormancy and reach homogeneous seedlings. Aril removal has been used as promisor method to increase seeds germination with several results in Passiflora species (Pereira and Dias, 2000; Martins et al., 2006; Osipi et al., 2011; Silva et al., 2015).

Additionally, passion fruit seeds are usually negative photoblastic, which means they are affected by light incidence; according to Brasil (2009), the germination test for $P$. edulis may be performed at darkness conditions to overcome seed dormancy. These results are in agreement with other authors, which were reported the light inhibitory effect in others Passiflora plants, such as $P$. cincinnata (Zucareli et al., 2009) and P. incarnata (Benvenuti et al., 2001; Zucareli et al., 2015). In this sense, the objective of this study was to evaluate the effect of aril removal methods and light conditions on P. edulis var. flavicarpa seeds quality and germination.

\section{Material and Methods}

\subsection{Seeds obtaining}

Sour passion fruits (Passiflora edulis var. flavicarpa) were bought at CEASA-Londrina, PR-Brazil. At the Fruits Analysis Laboratory of the Londrina State University, a sample with 15 fruits was collected to perform the physical characterization, as follow in the Table 1. Sixty-seven uniform fruits were chosen and cut to remove the pulp and seeds, which were homogenized in glass beaker (4 liters). Three pulp samples were collected to carry out the chemical analysis, according to IAL (2008) (Table 1). Then, the remaining pulp was divided into five similar amounts to test five methods of aril removal.

\subsection{Aril removal methods}

There were used five methods (treatments) to remove the seeds aril: (1) friction on steel mesh sieve for 5 minutes; (2) friction with coarse sand on steel mesh sieve for 5 minutes; (3) immersion in lime solution at 10\% (w/v), for 30 minutes; (4) fermentation in sugar solution at $10 \%$ (w/v), during 48 hours; and (5) natural pulp fermentation, during five days.

The treatments regarding fermentation were performed in glass beaker ( 2 liters) and kept at $22 \pm 2{ }^{\circ} \mathrm{C}$. The beakers were covered with a plastic film to prevent insects and the pulp was homogenized twice a day. After the fermentation periods, the pulps with seeds were washed under running water on steel mesh sieve. All seeds obtained in the treatments were kept to dry at $22 \pm 2{ }^{\circ} \mathrm{C}$ during five days and stored in paper bags at $3 \pm 1{ }^{\circ} \mathrm{C}$ until to the experimental installation.

\subsection{Analysis performed}

The seed water content (\%) was determined by the incubator method at $105{ }^{\circ} \mathrm{C}$ (Brasil, 2009), using two samples of 20 seeds for each treatment. The thousand seed mass was determined from eight samples of 100 seeds, according to Brasil (2009).

Seedling length test was performed in dark chamber at $25^{\circ} \mathrm{C}$, using four replications of 20 seeds per treatment on paper rolls, moistened with distilled water equivalent to 2.5 times the weight of the dry paper (Brasil, 2009). The seedling length was measured through the ruler and seedling dry matter weighted in a precision balance $(0.0001 \mathrm{~g})$, after drying at $70{ }^{\circ} \mathrm{C}$ during five days in an incubator.

For the germination test, four replications of 50 seeds were placed on paper rolls, previously moistened with distilled water equivalent to 2.5 times the weight of the dry paper (Brasil, 2009). The paper rolls were kept in germination chamber at $25^{\circ} \mathrm{C}$, under constant darkness and

Table 1. Physicochemical properties of fruits and pulp of sour passion fruits (Passiflora edulis var. flavicarpa). Color attributes of lightness $\left(L^{*}\right)$, saturation $\left(C^{*}\right)$ and hue angle $\left(h^{\circ}\right)$; fruit mass (FM); pulp mass (PM); fruit diameter (FD), soluble solids content (SS), pulp pH; titratable acidity (TA, \% of citric acid) and SS/TA.

\begin{tabular}{lccccc}
\hline & $\boldsymbol{L}^{*}$ & $\boldsymbol{C}^{*}$ & $\boldsymbol{h}^{\boldsymbol{o}}$ & FM (g) & PM (g) \\
\hline Average & 62.30 & 46.82 & 88.81 & 296.93 & 105.56 \\
SD & 2.83 & 4.00 & 1.51 & 48.68 & 17.36 \\
CV (\%) & 4.55 & 8.53 & 1.70 & 16.40 & 16.45 \\
\hline & FD $(\mathbf{m m})$ & SS $\left({ }^{\mathbf{0}}\right.$ Brix) & pH & TA (\%) & SS/TA \\
\hline Average & 92.40 & 11.37 & 3.89 & 3.88 & 2.93 \\
SD & 5.26 & 0.06 & 0.16 & 0.11 & 0.10 \\
CV $(\%)$ & 5.70 & 0.51 & 4.02 & 2.91 & 3.25 \\
\hline
\end{tabular}

$\mathrm{SD}=$ standard deviation; $\mathrm{CV}=$ coefficient of variation. 
lightness. From eighth day after experimental installation, the numbers of germinated seeds were recorded daily. The germination speed index (GSI) (Maguire, 1962) and the total germination were calculated, considering as normal seedlings those with proportional shoot and root (Brasil, 2009). For the germination test, performed at darkness and lightness conditions, the percentages were established from the $28^{\text {th }}$ and $25^{\text {th }}$ days after the test installation, respectively.

Seedling emergence test was carried out in a greenhouse applying a completely randomized design with four replications of 25 seeds per treatment. The seeds were sown in Styrofoam trays with 128 cells, one seed per cell, filled with semi-composted pine bark substrate and watered twice a day. Seedling emergence was recorded at $9^{\text {th }}, 17^{\text {th }}$ and $26^{\text {th }}$ days after the test installation evaluating normal seedlings with healthy shoot.

\subsection{Statistical analysis}

All data recorded were tested for normality and variance homogeneity; then, submitted to analysis of variance (ANOVA). The data recorded at germination test were subjected to analysis of join variances to compare the environments (darkness and lightness conditions), and the treatments means compared by Tukey's test at $5 \%$ probability level.

\section{Results}

The Passiflora edulis var. flavicarpa fruits showed intense bright yellow skin $\left(L^{*}=62.30\right.$ and $\left.h^{\circ} 88.81\right)$ and the pulp mass corresponded about $30 \%$ of the total mass (Table 1). The soluble solids content recorded was $11.37^{\circ} \mathrm{Brix}$, followed by maturation index of 2.93 (SS/TA ratio), which indicates that the seeds had already reached the physiological maturity.

Regarding the thousand seeds mass (Table 2), the values ranged from 22.30 to $23.03 \mathrm{~g}$ with non-significant alteration independently of the treatment used. Also, it was observed that seeds water content was similar between the treatments (max variation 1.77 percent point) showing that seeds from all treatment had the same metabolic level.

In relation to the seed germination test, performed in the darkness and lightness conditions, there were not significant interaction between aril removal methods and light conditions (Table 3); however, the results showed that in the darkness occurred the highest germination percentage (59\%) compared to lightness condition (47\%). Among the aril removal methods, the natural pulp fermentation during five days was the most appropriated method to overcome physiological seed dormancy caused through the aril presence, due to the highest germination percentage $(81 \%)$ followed by lime solution for 30 minutes. On the other hand, the pulp fermentation in sugar solution during 48 hours showed $37 \%$ of seeds germination, followed by friction on steel mesh sieve for 5 minutes (45\%).

The seed vigor evaluated by germination speed, at darkness, higher germination speed index (2.25) than lightness conditions (1.85), indicating that at darkness the germination occurs uniform (Table 3). Agreeing with the germination results for aril extraction methods, the natural pulp fermentation during five days showed superior germination speed index compared to other methods, being just equal to lime solution for 30 minutes that was the second high germination value.

Table 2. A thousand seeds mass (TSM), coefficient of variation (CV) and water content (WC) of Passiflora edulis var. flavicarpa seeds submitted to different aril removal methods.

\begin{tabular}{lccc}
\hline \multicolumn{1}{c}{ Treatment } & TSM (g) & CV (\%) & WC (\%) \\
\hline Friction on sieve & 22.30 & 1.88 & 8.42 \\
Friction with coarse sand on sieve & 22.76 & 1.59 & 8.38 \\
Immersion in lime solution & 22.72 & 1.54 & 7.96 \\
Pulp fermentation in sugar & 23.03 & 1.29 & 7.43 \\
Natural pulp fermentation & 22.86 & 1.22 & 9.20 \\
\hline
\end{tabular}

Table 3. Germination percentage and germination speed index (GSI) of Passiflora edulis var. flavicarpa seeds submitted to different aril removal methods and germination conditions.

\begin{tabular}{lcccccc}
\hline \multirow{2}{*}{\multicolumn{1}{c}{ Treatment }} & \multicolumn{2}{c}{ Germination (\%) } & \multirow{2}{*}{ Mean } & \multicolumn{2}{c}{ GSI } & \multirow{2}{*}{ Mean } \\
\cline { 2 - 3 } & Dark & Light & & Dark & Light & \\
\hline Friction on sieve & 50 & 40 & $45 \mathrm{~cd}^{*}$ & 1.86 & 1.43 & $1.65 \mathrm{~b}$ \\
Friction with coarse sand on sieve & 55 & 44 & $49 \mathrm{bc}$ & 2.10 & 1.78 & $1.94 \mathrm{~b}$ \\
Immersion in lime solution & 59 & 51 & $55 \mathrm{~b}$ & 2.35 & 2.40 & $2.38 \mathrm{a}$ \\
Pulp fermentation in sugar & 48 & 26 & $37 \mathrm{~d}$ & 1.91 & 1.20 & $1.56 \mathrm{~b}$ \\
Natural pulp fermentation & 86 & 76 & $81 \mathrm{a}$ & 3.05 & 2.45 & $2.75 \mathrm{a}$ \\
Mean & $59 \mathrm{~A}$ & $47 \mathrm{~B}$ & & $2.25 \mathrm{~A}$ & $1.85 \mathrm{~B}$ & \\
CV (\%) & \multicolumn{3}{c}{12.36} & & \multicolumn{2}{c}{14.08} \\
\end{tabular}

*Equal letters, lowercase in the column and uppercase in the row for each variable, do not differ by Tukey's test at 0.05 probability level; $\mathrm{CV}=$ coefficient of variation. 
Table 4. Seedlings length test, dry matter and emergence recorded at 9, 17 and 26-day after sowing (DAS) of Passiflora edulis var. flavicarpa seedlings submitted to different seed aril removal methods.

\begin{tabular}{lccccc}
\hline \multirow{2}{*}{ Treatment } & Length & Dry matter & \multicolumn{3}{c}{ Emergence (\%) } \\
\cline { 5 - 7 } & $(\mathbf{c m})$ & $(\mathbf{m g})$ & 9DAS & 17DAS & 26DAS \\
\hline Friction on sieve & $11.67 \mathrm{ab}{ }^{*}$ & $5.0^{\mathrm{ns}}$ & $43 \mathrm{ab}$ & $77^{\mathrm{ns}}$ & $88^{\mathrm{ns}}$ \\
Friction with coarse sand on sieve & $8.39 \mathrm{~b}$ & 4.0 & $41 \mathrm{ab}$ & 82 & 88 \\
Immersion in lime solution & $9.97 \mathrm{ab}$ & 5.0 & $38 \mathrm{ab}$ & 90 & 94 \\
Pulp fermentation in sugar & $14.48 \mathrm{a}$ & 6.0 & $26 \mathrm{~b}$ & 79 & 88 \\
Natural pulp fermentation & $11.35 \mathrm{ab}$ & 4.0 & $46 \mathrm{a}$ & 84 & 89 \\
CV (\%) & 18.84 & 18.55 & 23.28 & 12.38 & 7.64 \\
\hline
\end{tabular}

*Means followed by the same letters in the column do not differ statistically by Tukey's test at 0.05 probability level; ${ }^{\mathrm{n}}$ non-significant; $\mathrm{CV}=$ coefficient of variation.

For the length plants test, it was observed significant differences between the treatments friction with coarse sand on steel mesh sieve, for 5 minutes $(8.39 \mathrm{~cm})$, and fermentation in sugar solution at $10 \%(\mathrm{w} / \mathrm{v})$, during 48 hours $(14.48 \mathrm{~cm})$, caused mainly due to the mechanical embryo damage that the coarse sand promoted during the friction. Seedlings dry matter did not differ between the treatments (Table 4), which revels that even small seedlings had similar matter compensated by the lateral roots growth.

The Table 4 presents the data recorded according to emergence test. There were performed three emergence evaluations: at $9^{\text {th }}, 17^{\text {th }}$ and $26^{\text {th }}$ days after sowing (DAS). At $9^{\text {th }}$ DAS, significant differences were observed between the treatments T4 and T5. On the other hand, there were not noticed differences between the treatments in the other evaluations (at $17^{\text {th }}$ and $26^{\text {th }}$ DAS). The values observed for seedlings emergence ranged from 88 to $94 \%$, which can be considerate satisfactory for this species.

\section{Discussion}

The fruits ripening stage is a very important characteristic to determine the harvest moment and predict the seeds maturation; thus, it is important to determine and consider some ripening parameters to harvest these fruits (Table 1). Seeds collected from ripe and withered fruits presented higher germination percentage than seeds collected from ripe fruits, but not withered, 82 and $71 \%$, respectively (Lopes et al., 2007). However, in the present study the fruits were harvested before wrinkling and the seedlings emergence were higher than $88 \%$ (Table 4 ), it supposes that the seeds had already reached the physiological maturity. About the chemical fruits properties, similar results were reported by Pongener et al. (2014), which were observed soluble solids content ranging from 11.45 to 13.24 and titratable acidity from 3.04 to $2.53 \%$ of citric acid, in ripe Passiflora edulis fruits at harvest period.

Regarding the germination and emergence tests, it is possible to observe discrepant differences between them. The germination percentages recorded at darkness and lightness conditions were lower than the results observed in emergence test, except for seeds submitted at natural pulp fermentation during five days $(81 \%)$. There were observed exudates in some seeds during the germination final evaluation, which may have inhibited the germination process, whereas in the emergence test the water from irrigation probably leached the exudates, allowing more seeds to germinate. Similar result for low germination on paper substrate was reported by Ferrari et al. (2008), whose observed for $P$. alata $50 \%$ of normal seedlings even at alternating temperature $\left(20 / 30{ }^{\circ} \mathrm{C}\right)$; however, these authors did not describe the aril removal method applied in their study.

For aril remove, there was observed that the natural pulp fermentation during five days may have reduced or degraded inhibitory substances even on paper substrate. This indicates that this method promoted the total aril removal and allowed seeds to germinate (Table 3 ).

Osipi et al. (2011) testing aril removal methods in $P$. alata seeds observed higher germination for friction on sieve method (45\%), followed by natural fermentation during five days $(23.5 \%)$ and friction on sieve using sand $(9 \%)$, when the test was performed in the dark at alternating temperature $\left(20 / 30^{\circ} \mathrm{C}\right)$. On the other hand, for P. edulis var. flavicarpa, the natural pulp fermentation for aril removal did not affect the seeds germination (Martins et al., 2006; Pereira and Dias, 2000). Therefore, according to the literature and the results obtained in this study, there was observed that the effect of the method to remove the aril might vary from specie to specie.

Concerning to the light influence on seeds germination, some authors have recommended performing Passiflora species germination test in darkness because the constant light may inhibit the seeds germination (Benvenuti et al., 2001; Brasil, 2009; Zucareli et al., 2009, 2015). In this study was reported that constant light did not affect the seeds germination, although in light was observed the lowest germination percentages. Similar results were reported by Benvenuti et al. (2001) for P. incarnata in the germination test carried out at lightness and darkness; the germination percentage observed at darkness was superior to those recorded at lightness, independent the temperature used for the germination test.

Since the sour passion fruits have presented a considerably economic importance, this species has gone through the breeding programs and selections; thus, some 
characteristics may have been lost, among them, the seeds darkness responses.

The seedlings emergence was observed from the $9^{\text {th }}$ day after sowing, with seedlings emergence ranged from 26 to $46 \%$. Ferreira et al. (2007) using plant growth regulator $\left(\right.$ Stimulate $\left.^{\circledR}\right)$ on P. edulis seeds, observed similar values for seedlings emergence using Rendmax as substrate. In contrast, the seedlings emergence shows to be depend of the different substrates as observed for $P$. edulis, which started at $17^{\text {th }}$ days after sowing (Aguiar et al., 2014).

Regarding the seedlings final emergence results, the aril removal methods did not affect the emergence percentage. Similar results were observed by Aguiar et al. (2014) for $P$. edulis with non-significant differences between the methods used to remove the aril and the seedlings emergence, except for the mechanical method (blender), which promoted lower seedlings emergence.

These results are in disagreement to Osipi et al. (2011), whom observed a significant influence for the aril removal method on $P$. alata seedlings emergence. The high seedlings emergence was observed for the friction on sieve using sand method to remove the aril, followed by the lime, $\mathrm{HCl}$ and natural fermentation methods.

The differences observed between germination and emergence tests are interesting, and suppose that the effect of the aril removal methods on seeds germination are superadded by the emergence test conditions, developing higher percentages of normal seedlings (Osipi et al., 2011).

The emergence test results observed in this study $(90 \%)$ and those observed by Aguiar et al. (2014), also 90\%, and Santos et al. (2015), more than $90 \%$, for the same specie are higher than the results recorded in the germination test for that and other studies e. g. Martins et al. (2006), Pereira and Dias (2000) and Santos et al. (2013). Thus, it is possible that recommend the seedlings emergence test like the most appropriate test to analyze $P$. edulis seeds quality. Although the germination test on paper is usually recommended as germination test standard for a lot of species; however, for $P$. edulis the best results were recorded in the emergence test. The aril removal methods did not affect the seedlings emergence in Passiflora edulis var. flavicarpa seeds.

\section{References}

AGUIAR, R.S., YAMAMOTO, L.Y., PRETI, E.A., SOUZA, G.R.B., SBRUSSI, C.A.G., OLIVEIRA, E.A.P., ASSIS, A.M., ROBERTO, S.R. and NEVES, C.S.V.J., 2014. Extração de mucilagem e substratos no desenvolvimento de plântulas de maracujazeiro-amarelo. Semina: Ciências Agrárias, vol. 35, no. 2, pp. 605-612. http://dx.doi.org/10.5433/1679-0359.2014v35n2p605.

ALEXANDRE, R.S., WAGNER JÚNIOR, A., NEGREIROS, J.R.S., PARIZZOTTO, A. and BRUCKNER, C.H., 2004. Germinação de sementes de genótipos de maracujazeiro. Pesquisa Agropecuária Brasileira, vol. 39, no. 12, pp. 1239-1245. http:// dx.doi.org/10.1590/S0100-204X2004001200011.

ARAÚJO, E.C., DAHER, R.F., SILVA, R.F. and VIANA, A.P., 2007. Path analysis for physiological traits that influence seed germination of Passiflora edulis f. flavicarpa Deg. Crop Breeding and Applied Biotechnology, vol. 7, no. 2, pp. 148-154. http:// dx.doi.org/10.12702/1984-7033.v07n02a06.

BENVENUTI, S., SIMONELLI, G. and MACCHIA, M., 2001. Elevated temperature and darkness improve germination in Passiflora incarnata L. seed. Seed Science and Technology, vol. 29, pp. 533-541.

BEWLEY, J.D., BRADFORD, K., HILHORST, H. and NONOGAKI, H., 2013. Seeds: physiology of development, germination and dormancy. 3rd ed. New York: Springer, 392 p. http://dx.doi.org/10.1007/978-1-4614-4693-4

BRASIL. Ministério da Agricultura, Pecuária e Abastecimento, 2009. Regras para análises de sementes. Brasília: MAPA/ACS, 395 p.

CAMPOS, V.B., CAVALCANTE, L.F., DANTAS, T.A.G., MOTA, J.K.M., RODRIGUES, A.C. and DINIZ, A.A., 2007. Caracterização física e química de frutos de maracujazeiro amarelo sob adubação potássica, biofertilizante e cobertura morta. Revista Brasileira de Produtos Agroindustriais, vol. 9, no. 1, pp. 59-71. http://dx.doi.org/10.15871/1517-8595/rbpa.v9n1p59-71.

DALLING, J.W., DAVIS, A.S., SCHUTTE, B.J. and ARNOLD, A.E., 2011. Seed survival in soil: Interacting effects of predation, dormancy and the soil microbial community. Journal of Ecology, vol. 99, no. 1, pp. 89-95. http://dx.doi.org/10.1111/j.13652745.2010.01739.x.

DELANOY, M., VAN DAMME, P., SCHELDEMAN, X. and BELTRAN, J., 2006. Germination of Passiflora mollissima (Kunth) L.H. Bailey, Passiflora tricuspis Mast. and Passiflora nov sp. seeds. Scientia Horticulturae, vol. 110, no. 9, pp. 198-203. http://dx.doi.org/10.1016/j.scienta.2006.07.007.

FALEIRO, F.G., JUNQUEIRA, N.T.V. and BRAGA, M.F., 2005. Germoplasma e melhoramento genético do maracujazeiro-desafios da pesquisa. In: F.G. FALEIRO, N.T.V. JUNQUEIRA and M.F. BRAGA, eds. Maracujá-germoplasma e melhoramento genético. Planaltina: Embrapa Cerrados, pp. 187-210.

FERRARI, T.B., FERREIRA, G., MISCHAN, M.M. and PINHO, S.Z., 2008. Germinação de sementes de maracujá-doce (Passiflora alata Curtis): Fases e efeito de reguladores vegetais. Biotemas, vol. 21, no. 3, pp. 65-74. http://dx.doi.org/10.5007/2175$7925.2008 \mathrm{v} 21 \mathrm{n} 3 \mathrm{p} 65$.

FERREIRA, G., COSTA, P.N., FERRARI, T.B., RODRIGUES, J.D., BRAGA, J.F. and JESUS, F.A., 2007. Emergência e desenvolvimento de plântulas de maracujazeiro azedo oriundas de sementes tratadas com bioestimulante. Revista Brasileira de Fruticultura, vol. 29, no. 3, pp. 595-599. http://dx.doi.org/10.1590/ S0100-29452007000300034.

HANSEN, A.K., GILBERT, L.E., SIMPSON, B.B., DOWNIE, S.R., CERVI, A.C. and JANSEN, R.K., 2006. Phylogenetic relationships and chromosome number evolution in Passiflora. Systematic Botany, vol. 31, no. 1, pp. 138-150. http://dx.doi. org/10.1600/036364406775971769.

INSTITUTO ADOLFO LUTZ - IAL, 2008. Physicochemical methods for food analysis. São Paulo: IAL.

LOPES, J.C., BONO, G.M., ALEXANDRE, R.S. and MAIA, V.M., 2007. Germinação e vigor de plantas de maracujazeiroamarelo em diferentes extratos de maturação do fruto, arilo e substrato. Ciência e Agrotecnologia, vol. 31, no. 5, pp. 1340-1346. http://dx.doi.org/10.1590/S1413-70542007000500010.

MAGUIRE, J.D., 1962. Speed of germination-aid in selection and evaluation for seedling emergence and vigor. Crop Science, 
vol. 2, no. 1, pp. 176-177. http://dx.doi.org/10.2135/cropsci196 2.0011183X000200020033x.

MARCOS-FILHO, J., 2015. Fisiologia de sementes de plantas cultivadas. 2nd ed. Londrina: ABRATES, $660 \mathrm{p}$.

MARTINS, M.R., REIS, M.C., MENDES NETO, J.A., GUSMÃO, L.L. and GOMES, J.J.A., 2006. Influência de diferentes métodos de remoção do arilo na germinação de sementes de maracujazeiroamarelo (Passiflora edulis Sims f. flavicarpa Deg.). Revista da FZVA, vol. 13, no. 2, pp. 28-38.

OSIPI, E.A.F., LIMA, C.B. and COSSA, C.A., 2011. Influência de métodos de remoção do arilo na qualidade fisiológica de sementes de Passiflora alata Curtis. Revista Brasileira de Fruticultura, vol. 33, no. spe1, pp. 680-685. http://dx.doi.org/10.1590/S010029452011000500095.

PANTANO, C.S., 2007. Propagação. In: S. LEONEL and A.C. SAMPAIO, eds. Maracujá doce: aspectos técnicos e econômicos. São Paulo: UNESP, 134 p.

PEREIRA, K.J.C. and DIAS, D.C.F., 2000. Germinação e vigor de sementes de maracujá-amarelo (Passiflora edulis Sims f. flavicarpa Deg.) submetidas a diferentes métodos de remoção da mucilagem. Journal of Seed Science, vol. 22, no. 1, pp. 288-291.

PONGENER, A., SAGAR, V., PAL, R.K., ASREY, R., SHARMA, R.R. and SINGH, S.K., 2014. Physiological and quality changes during postharvest ripening of purple passion fruit (Passiflora edulis Sims). Fruits, vol. 69, no. 1, pp. 19-30. http://dx.doi.org/10.1051/fruits/2013097.

SANTOS, C.A.C., VIEIRA, E.L., PEIXOTO, C.P. and LEDO, C.A.S., 2013. Germinação de sementes e vigor de plântulas de maracujazeiro amarelo submetidos à ação do ácido giberélico. Bioscience Journal, vol. 29, no. 2, pp. 400-407.

SANTOS, C.E.M., MORGADO, M.A.D., MATIAS, R.G.P., WAGNER JÚNIOR, A. and BRUCKNER, C.H., 2015. Germination and emergence of passion fruit (Passiflora edulis) seeds obtained by self and open-pollination. Acta Scientiarum. Agronomy, vol. 37, no. 4, pp. 489-493. http://dx.doi.org/10.4025/ actasciagron.v37i4.19616.

SILVA, S.M., OLIVEIRA, R.C., ALMEIDA, R.F., SÁ JÚNIOR, A. and SANTOS, C.M., 2015. Aryl removal methods and passion fruit seed positions: Germination and emergence. Journal of Seed Science, vol. 37, no. 2, pp. 125-130. http://dx.doi.org/10.1590/2317$1545 \mathrm{v} 37 \mathrm{n} 2146373$.

TOZZI, H.H. and TAKAKI, M., 2011. Histochemical analysis of seed reserve mobilization in Passiflora edulis Sims fo. flavicarpa $\mathrm{O}$. Deg. (yellow passion fruit) during germination. Brazilian Journal of Biology $=$ Revista Brasileira de Biologia, vol. 71, no. 3, pp. 701-708. http://dx.doi.org/10.1590/S1519-69842011000400015. PMid:21881794.

ZUCARELI, V., FERREIRA, G., AMARO, A.C.E. and ARAÚJO, F.P., 2009. Fotoperíodo, temperatura e reguladores vegetais na germinação de sementes de Passiflora cincinnata Mast. Journal of Seed Science, vol. 31, no. 3, pp. 106-114. http:// dx.doi.org/10.1590/S0101-31222009000300012.

ZUCARELI, V., HENRIQUE, L.A.V. and ONO, E.O., 2015. Influence of light and temperature on the germination of Passiflora incarnata L. seeds. Journal of Seed Science, vol. 37, no. 2, pp. 162-167. http://dx.doi.org/10.1590/2317-1545v37n2147082. 